Young Bear of the Musquakies, of Tama, tells us he is acquainted with the bean Doctor Gilmore describes, with the uses he imputes to it and with the practice of taking the beans from the winter store of the mice. He says also that his people never failed to substitute for the bean something to maintain mouse life.

Apropos of this subject we quote from "The History of the Lewis and Clark Expedition," by Elliott Coues, Vol. I, page 161, as follows: "We visited both the villages, and sat conversing with the chiefs for some time, during which they presented us with a bread made of corn and beans, also corn and beans boiled; and a large rich bean which they take from the mice of the prairie; which discover and collect it." This is in the language of Lewis and Clark, written under date of October 11, 1804 , on page 103 of their original journal. Their camp that day was on the east side of the Missouri River, about twelve miles above where the Grand River empties into the Missouri from the west, or in the southwest part of what is now Campbell County, South Dakota.

\title{
J. D. EDMUNDSON CALLS ATTENTION TO INACCURACIES
}

Our friend, J. D. Edmundson, has called our attention to an apparent error in the January, 1921, edition of the ANNaLs, in connection with our reprint of "Galland's Iowa Emigrant." Toward the end of that reprint there is included "An Act now in force in Iowa," (the date of publishing the Galland book was 1840 ) and at the end of the act occur the words, "Approved January 19, 1838." Now the first Territorial Assembly of Iowa Territory did not convene until November 12, 1838, so how could the act have been approved before the convening of the assembly? On investigation we find this particular act was enacted by the Territorial Legislature of Wisconsin, being cited as "Act No. 97, of the Territorial Legislature of 1837-38," and "received the governor's approval January 19, 1838." What afterward became Iowa was then a part of Wisconsin Territory, so that act became "in force" in what afterwards was Iowa. When Iowa Territory was formed the laws of Wisconsin Territory prevailed in Iowa so far as applicable, but when the first legislative as- 
sembly of Iowa Territory met in November, 1838, it proceeded, among other things, to re-enact those of the Wisconsin statutes it desired, and among others it re-enacted this particular one which is set out in Galland's book, and it received the governor's approval on January 25,1839 , the very last day of the session. (See Statutes of the Territory of Iowa, First Session, page 389.) Dr. Galland must have had the copy of the Wisconsin statute with its date of approval before him when he wrote the copy for his book, but at the date of publication which the book bears, 1840, the Iowa statute with its date of approval, was the one he should have used.

Mr. Edmundson also corrects a footnote in "Beginnings" by Tacitus Hussey, where at page $32 \mathrm{Mr}$. A. D. Jones is credited with laying out the city of Council Bluffs. We set out below a copy of an affidavit narrating the truth with respect to this:

THOMAS TOSTEVIN (THOS) To

THE PUBLIC

\section{AFFIDAVIT}

Sworn 19 January, 1904

Filed with Abstract Company

On oath states:-I am and have been since the year 1854, a resident of the City of Council Bluffs, Iowa; my profession is that of a Civil Engineer and Surveyor; that I am familiar with the location of the land for which Franklin Street, as County Judge of Pottawattamie County, Iowa, received Patent from the United States Government, which are as follows:-(among other) SE1/4 Section 25, Township 75, Range 44.

That in the spring of 1854 under the direction of Franklin Street, County Judge as aforesaid, I completed a survey of a portion of said lands which survey was made for the purpose of assisting said County Judge in carrying out the provisions of the Act of the Legislative Assembly of the State of Iowa, relative to the disposal of said lands, that I surveyed the different claims of the various occupants, giving each a description by metes and bounds and numbered each and all of said claims as lots, which from that time were and still are designated as Original Plat Lots in said City; that same metes and bounds descriptions are of record in the office of the Recorder of Pottawattamie County, Iowa, in Book $\mathbf{K}$, of said records.

Sworn 19 January, 1904, before H. F. Rohling, Notary Public (seal) Pottawattamie County, Iowa.

\section{GREGG'S DOLLAR MONTHLY.}

In this issue we are publishing several articles from Gregg's Dollar Monthly and Old-Settlers' Memorial, recently acquired, which was published at Hamilton, Illinois, in 1873, 1874 and 
Copyright of Annals of Iowa is the property of State of Iowa, by \& through the State Historical Society of Iowa and its content may not be copied or emailed to multiple sites or posted to a listserv without the copyright holder's express written permission. However, users may print, download, or email articles for individual use. 